\title{
Global costs attributed to chronic kidney disease: a systematic review
}

(iD) Geraldo Bezerra da Silva Junior, ${ }^{1,2}$ Juliana Gomes Ramalho de Oliveira' Marcel Rodrigo Barros de Oliveira ${ }^{3}$ Luiza Jane Eyre de Souza Vieira ${ }^{1}$ Eduardo Rocha Dias ${ }^{4}$

\footnotetext{
1. Postgraduate Program in Collective Health, Health Sciences Center, University of Fortaleza. Fortaleza (CE), Brasil 2. Department of Epidemiology and Prevention of Renal Disease, Brazilian Society of Nephrology. São Paulo (SP), Brasil 3. Nephrology Service, General Hospital of Fortaleza. Fortaleza (CE), Brasil 4. Postgraduate Program in Constitutional Law, Center for Legal Sciences, University of Fortaleza. Fortaleza (CE), Brasil
}

\section{SUMMARY}

The aim of this study is to discuss the global costs attributed to chronic kidney disease (CKD) and its impact on healthcare systems of developing countries, such as Brazil. This is a systematic review based on data from PubMed/Medline, using the key words "costs" and "chronic kidney disease", in January 2017. The search was also done in other databases, such as Scielo and Google Scholar, aiming to identify regional studies related to this subject, published in journal not indexed in PubMed. Only papers published from 2012 on were included. Studies on CKD costs and treatment modalities were prioritized. The search resulted in 392 articles, from which 291 were excluded because they were related to other aspects of CKD. From the 101 remaining articles, we have excluded the reviews, comments and study protocols. A total of 37 articles were included, all focusing on global costs related to CKD. Despite methods and analysis were diverse, the results of these studies were unanimous in alerting for the impact (financial and social) of CKD on health systems (public and private) and also on family and society. To massively invest in prevention and measures to slow CKD progression into its end-stages and, then, avoid the requirement for dialysis and transplant, can represent a huge, and not yet calculated, economy for patients and health systems all over the world.

KEYWORDS: Chronic kidney disease. Dialysis. Kidney Transplant. Health care costs.

\section{INTRODUCTION}

Chronic kidney disease (CKD) is fast growing in Brazil and worldwide, and is associated with high financial expenditures for patients and healthcare systems. Scaling up its economic repercussions and proposing strategies to minimize the costs involved in its treatment has been configured as a challenge for the scientific community.

Defined as the presence of kidney damage or decreased kidney function for three months or more, with repercussions on the general state of the pa- tient $^{1}$, CKD has as its main causes systemic arterial hypertension (SAH) (35\%) and diabetes mellitus (DM) $(30 \%)^{2}$, both chronic non-communicable diseases (CNCDs) with a high impact on morbidity and mortality and with high prevalence worldwide. In addition, CKD has a strong relationship with aging ${ }^{3}$ and, based on the Brazilian population, according to projections, by 2050, the estimated number of elderly will be 66 million, while children and adolescents will be 31.8 million, reversing the scenario of 2010 , 
when values for these age groups were 19.6 and 49.9 million, respectively. ${ }^{4}$

In general, aging is related to the risk of multi-morbidity, that is, the individual is affected by more than one chronic illness at the same time, which generates greater use of healthcare services and a considerable increase in treatment costs, considering that these are proportional to the number of associated diseases $^{5}$. Population aging, if analysed in isolation, already presents numerous challenges for all sectors of society and imposes the need to rethink the dimension of the supply of services needed to meet the demands of this population group in the long term ${ }^{4}$.

In the more advanced stages of CKD, characterized by a severe decline in the glomerular filtration rate (GFR), the patient must initiate one of the modalities of renal replacement therapy (RRT), whose current options are haemodialysis (HD), peritoneal dialysis (PD) and kidney transplant. Such therapeutic options demand numerous expenses for the healthcare system because, in addition to having a high cost, its users are susceptible to prolonged hospitalizations, continuous treatment and the use of high cost medications. It is known that dialysis and kidney transplant consume disproportionate amounts of healthcare budgets, since about $5 \%$ of budgets are consumed by less than $1 \%$ of the population'.

Studies of financial growth suggest that the greatest macroeconomic burden of CKD and other chronic diseases falls on low- and middle-income countries, where high prevalence and high treatment costs create a proportional burden on gross domestic product $(G D P)^{6}$. It is known that the provision of RRT by countries has a directly proportional relation with their GDP, suggesting that poverty is an important disadvantage with respect to the access of individuals to the modalities of CKD treatment ${ }^{7}$. In addition, in the personal sphere, expenditures attributed to healthcare commonly affect the family financial structure, with considerable property loss, in a context of insufficient resources.

Faced with global financial instability, the uncertainties surrounding healthcare financing in developing and underdeveloped countries, the certainty of increasing life expectancy and the consequent increase in chronic health conditions, this review proposes to discuss financial costs attributed to CKD and its repercussions on healthcare systems in developing countries, such as Brazil.

\section{MATERIALS AND METHODS}

This is a systematic review carried out in the PubMed/Medline database, using the terms "costs" and "chronic kidney disease", in January 2017. The search was expanded to other bases, such as Scielo and Google Scholar, with the purpose of identifying local studies related to this matter, published in journals not indexed in PubMed. Only articles published since 2012 have been included, considering the period of the last five years as recent. Studies focused on the costs of CKD and its treatment modalities were prioritized. The studies focused on the cost-effectiveness of drug regimens and therapeutic behaviours were excluded. The detailed selection process of the articles is described in Figure 1.

FIGURE 1: SELECTION PROCESS OF ARTICLES ON THE COSTS OF CHRONIC KIDNEY DISEASE FOUND IN THE SYSTEMATIC REVIEW AND INCLUSION/EXCLUSION CRITERIA.

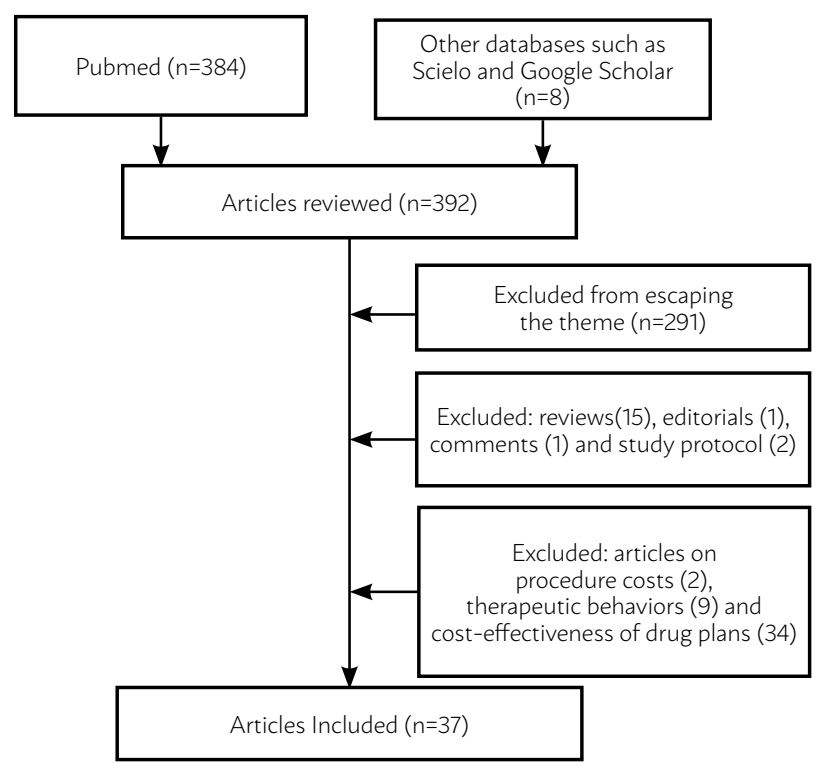

\section{RESULTS}

In total, the search resulted in 392 articles (PubMed and other sources), of which 291 were excluded because they avoided the main theme of this review. Of the remaining 101, 19 articles were excluded because they were reviews, comments and study protocols, and 45 because they deal with costs of procedures, therapeutic behaviours and cost-effectiveness of specific drug regimens. The study included 37 articles focused on the overall costs related to CKD (Table 1). 
TABLE 1: STUDY ON THE OVERALL COSTS RELATED TO CKD

\begin{tabular}{|c|c|c|c|c|c|}
\hline Main Author & Year & Country & Study Model & Study Object & Primary Conclusion \\
\hline Small (8) & 2017 & United States & Cross-sectional & Costs of CKD treatment & $\begin{array}{l}\text { The costs of patients with CKD who do not } \\
\text { go through dialysis are high and may be } \\
\text { equal to or higher than those of cancer or } \\
\text { CVA patients. }\end{array}$ \\
\hline Damien (9) & 2016 & United States & Cross-sectional & Costs of CKD treatment & $\begin{array}{l}\text { Therapeutic follow-up before and after the } \\
\text { beginning of dialysis and the managing } \\
\text { of comorbidities are potential sources of } \\
\text { savings in CKD care. }\end{array}$ \\
\hline Eriksson (10) & 2016 & Sweden & Cohort & Costs of CKD treatment & $\begin{array}{l}\text { In comparison with the general population, } \\
\text { the average yearly costs for CKD treatment } \\
\text { are higher in all its modalities. }\end{array}$ \\
\hline $\begin{array}{l}\text { Anutrakulchai } \\
\text { (11) }\end{array}$ & 2016 & Thailand & Cross-sectional & $\begin{array}{l}\text { Clinical outcomes and } \\
\text { treatment costs for CKD }\end{array}$ & $\begin{array}{l}\text { The group of hospitalized CKD patients } \\
\text { who presented the fewest benefits and } \\
\text { highest mortality was composed of farmers, } \\
\text { low-income, and unemployed individuals. }\end{array}$ \\
\hline Silva (12) & 2016 & Brazil & Environmental & $\begin{array}{l}\text { Socioeconomic and mor- } \\
\text { tality aspects for patients } \\
\text { with CKD }\end{array}$ & $\begin{array}{l}\text { Men and the elderly presented the highest } \\
\text { mortality. Associated with a high preva- } \\
\text { lence, kidney transplant (deceased donor) } \\
\text { and HD presented the highest costs. }\end{array}$ \\
\hline Turchetti (13) & 2016 & Italy & Cross-sectional & $\begin{array}{l}\text { Social cost per CKD } \\
\text { patient stages } 4-5 \text { pre-di- } \\
\text { alysis }\end{array}$ & $\begin{array}{l}\text { The indirect and non-medical direct costs } \\
\text { from CKD treatment were similar to the } \\
\text { direct costs. }\end{array}$ \\
\hline Kerr (14) & 2016 & England & Cross-sectional & $\begin{array}{l}\text { Cause, site, and hospital } \\
\text { costs related to the death } \\
\text { of CKD patients }\end{array}$ & $\begin{array}{l}\text { The primary causes for the death of CKD } \\
\text { patients were not kidney related. Deaths } \\
\text { at home are associated with a reduction of } \\
\text { hospital costs. }\end{array}$ \\
\hline Roggeri (15) & 2016 & Italy & Retrospective cohort & Costs of CKD treatment & $\begin{array}{l}\text { CKD is associated with a high economic } \\
\text { burden and the beginning of dialysis with an } \\
\text { increase in direct costs with health care. }\end{array}$ \\
\hline Mendu (!6) & 2016 & United States & Retrospective cohort & $\begin{array}{l}\text { Rational clinical criteria for } \\
\text { the diagnosis of CKD. }\end{array}$ & $\begin{array}{l}\text { Some clinical criteria can guide the diagno- } \\
\text { sis of CKD and reduce its costs. }\end{array}$ \\
\hline Silva (17) & 2016 & Brazil & $\begin{array}{l}\text { Cost analysis/Litera- } \\
\text { ture review }\end{array}$ & Costs of CKD treatment & $\begin{array}{l}\text { Kidney transplant stood out as the best } \\
\text { alternative from a financial and clinical } \\
\text { point of view, under the perspective of the } \\
\text { Unified Health System (SUS). }\end{array}$ \\
\hline Kulkarni (18) & 2015 & India & Cross-sectional & Costs of CKD treatment & $\begin{array}{l}\text { The costs of HD in India are high when } \\
\text { compared with the per capita income in the } \\
\text { country. }\end{array}$ \\
\hline Atapour (19) & 2015 & Iran & Cross-sectional & Costs of CKD treatment & PD presents a lower cost lower than HD. \\
\hline Ferguson (20) & 2015 & Canada & Cost models & $\begin{array}{l}\text { Operation costs for dialysis } \\
\text { units }\end{array}$ & $\begin{array}{l}\text { HD units in remote areas are more expen- } \\
\text { sive, per patient, than hospital HD in urban } \\
\text { areas. }\end{array}$ \\
\hline Francis (21) & 2015 & Peru & Cross-sectional & CKD demographics & $\begin{array}{l}\text { The high prevalence rates of CKD in Lima } \\
\text { and Tumbes are compatible with high-in- } \\
\text { come countries. }\end{array}$ \\
\hline Takura (22) & 2015 & Japan & $\begin{array}{l}\text { Cost-effectiveness } \\
\text { analysis }\end{array}$ & $\begin{array}{l}\text { Cost-effectiveness of CKD } \\
\text { treatment. }\end{array}$ & $\begin{array}{l}\text { Hemodiafiltration is a cost-effective } \\
\text { therapy. }\end{array}$ \\
\hline Wyld (23) & 2015 & Australia & Cohort & Costs of CKD treatment & $\begin{array}{l}\text { CKD patients spend } 85 \% \text { more on health } \\
\text { treatments and } 50 \% \text { more government } \\
\text { subsidies than individuals with no CKD, and } \\
\text { costs rise as the disease progresses. }\end{array}$ \\
\hline Ozieh (24) & 2015 & United States & Cross-sectional & $\begin{array}{l}\text { The costs for CKD treat- } \\
\text { ment on DM patients }\end{array}$ & $\begin{array}{l}\text { CKD significantly contributes to the treat- } \\
\text { ment costs for individuals with DM. }\end{array}$ \\
\hline Kent (25) & 2015 & England & Cohort & Costs of CKD treatment & $\begin{array}{l}\text { RRT and vascular events are the leading } \\
\text { causes of the rising costs in CKD treatment. }\end{array}$ \\
\hline Brunelli (26) & 2015 & United States & Retrospective cohort & $\begin{array}{l}\text { Costs for CKD treatment } \\
\text { in individuals with autoso- } \\
\text { mal dominant polycystic } \\
\text { kidney disease. }\end{array}$ & $\begin{array}{l}\text { The use and costs of health care for patients } \\
\text { with autosomal dominant polycystic kidney } \\
\text { disease and CKD in the terminal stage in } \\
\text { dialysis are high. }\end{array}$ \\
\hline Blanchette (27) & 2015 & United States & Cross-sectional & $\begin{array}{l}\text { Costs for CKD treatment } \\
\text { in individuals with autoso- } \\
\text { mal dominant polycystic } \\
\text { kidney disease. }\end{array}$ & $\begin{array}{l}\text { Patients with autosomal dominant polycys- } \\
\text { tic kidney disease presented higher rates of } \\
\text { renal procedures, which can contribute to } \\
\text { the rising costs of treatment. }\end{array}$ \\
\hline
\end{tabular}




\begin{tabular}{|c|c|c|c|c|c|}
\hline Main Author & Year & Country & Study Model & Study Object & Primary Conclusion \\
\hline Medway (28) & 2015 & Australia & Qualitative & $\begin{array}{l}\text { Financial impact of CKD in } \\
\text { children }\end{array}$ & $\begin{array}{l}\text { For parents, the impossibility of keeping } \\
\text { their jobs combined with medical and } \\
\text { non-medical expenses where the primary } \\
\text { factors with a financial impact. }\end{array}$ \\
\hline Menezes (29) & 2015 & Brazil & $\begin{array}{l}\text { Cross-sectional/ret- } \\
\text { rospective cohort }\end{array}$ & Costs of CKD treatment & $\begin{array}{l}\text { A considerable increase in the number of } \\
\text { HD sessions and their cost was found, from } \\
2008 \text { to } 2012 \text {. }\end{array}$ \\
\hline Nassir (30) & 2015 & United States & Cohort & Costs of CKD treatment & $\begin{array}{l}\text { No association was found between the rela- } \\
\text { tive costs of the treatment and the failure of } \\
\text { the kidney grafts. }\end{array}$ \\
\hline $\begin{array}{l}\text { Villarreal-Rios } \\
\text { (31) }\end{array}$ & 2014 & Mexico & Cross-sectional & Costs of CKD treatment & $\begin{array}{l}\text { The high costs of CKD pose a serious prob- } \\
\text { lem for healthcare services and families. } \\
\text { CAPD is the most cost-efficient option for } \\
\text { both. }\end{array}$ \\
\hline Satyavani (32) & 2014 & India & Cross-sectional & $\begin{array}{l}\text { The costs for CKD treat- } \\
\text { ment on DM patients }\end{array}$ & $\begin{array}{l}\text { The direct costs of hospital admissions for } \\
\text { treating CKD are considerably higher than } \\
\text { those of the patients who suffer from the } \\
\text { complication. }\end{array}$ \\
\hline $\begin{array}{l}\text { Lorenzo-Sel- } \\
\text { lares (33) }\end{array}$ & 2014 & Spain & Cohort & Costs of CKD treatment & $\begin{array}{l}\text { HD is five times more expensive than the } \\
\text { treatment for advanced stages of CKD and } \\
\text { three times the costs for kidney transplan- } \\
\text { tation. }\end{array}$ \\
\hline Moura (34) & 2014 & Brazil & Environmental & $\begin{array}{l}\text { Incidence and prevalence } \\
\text { of patients on dialysis who } \\
\text { rely on public financing }\end{array}$ & $\begin{array}{l}\text { During the time of the study, there was a } \\
\text { constant increase in incidence, and preva- } \\
\text { lence rose, especially amongst the elderly. }\end{array}$ \\
\hline $\begin{array}{l}\text { Gador-Whyte } \\
\text { (35) }\end{array}$ & 2014 & Australia & Cross-sectional & $\begin{array}{l}\text { Costs for implementing } \\
\text { protocols for CKD and DM } \\
\text { treatment }\end{array}$ & $\begin{array}{l}\text { Adherence to best practices for DM and } \\
\text { CKD treatment was compromised by } \\
\text { inadequate financing and matters related to } \\
\text { the workforce. }\end{array}$ \\
\hline Karopadi (36) & 2014 & Italy & Meta-analysis & Costs of CKD treatment & $\begin{array}{l}\text { Even in the absence of a market for the } \\
\text { local production of PD equipment, it is } \\
\text { possible for a country to save with the } \\
\text { provision of PD. }\end{array}$ \\
\hline Vupputuri (37) & 2014 & United States & Retrospective cohort & $\begin{array}{l}\text { The costs for CKD treat- } \\
\text { ment on DM patients }\end{array}$ & $\begin{array}{l}\text { The progression of CKD in DM type } 2 \\
\text { patients substantially increases treatment } \\
\text { costs. }\end{array}$ \\
\hline Kadam (38) & 2013 & England & Cross-sectional & $\begin{array}{l}\text { Treatment costs for chron- } \\
\text { ic diseases }\end{array}$ & $\begin{array}{l}\text { Multimorbidity is associated with a broad } \\
\text { variety of treatments and different costs. } \\
\text { CKD is one of the diseases with the highest } \\
\text { and most expensive impact in healthcare. }\end{array}$ \\
\hline Coentrão (39) & 2013 & Portugal & Retrospective cohort & Costs of CKD treatment & $\begin{array}{l}\text { Compared with HD, PD requires fewer } \\
\text { resources over the first year of treatment. }\end{array}$ \\
\hline Essue (40) & 2013 & Australia & Cross-sectional & Costs of CKD treatment & $\begin{array}{l}\text { A considerable proportion of the patients } \\
\text { face difficulties due to the high costs asso- } \\
\text { ciated with the treatment and managing } \\
\text { od CKD. }\end{array}$ \\
\hline Erdem (41) & 2013 & United States & Cross-sectional & $\begin{array}{l}\text { Treatment costs for chron- } \\
\text { ic diseases }\end{array}$ & $\begin{array}{l}\text { People with chronic diseases represent a } \\
\text { disproportionate share of Medicare pay- } \\
\text { ments, both for Part A and for Part B, over } \\
\text { a period of two years. CKD is among the } \\
\text { most expensive chronic diseases, in both } \\
\text { parts. }\end{array}$ \\
\hline $\begin{array}{l}\text { Ramachandran } \\
\text { (42) }\end{array}$ & 2013 & India & Cohort & Costs of CKD treatment & $\begin{array}{l}\text { Kidney transplant is associated with cata- } \\
\text { strophic spendings and leads most patients } \\
\text { who are treated in a public hospital to a } \\
\text { serious financial crisis, as well as to school } \\
\text { evasion and loss of employment. }\end{array}$ \\
\hline Chiroli (43) & 2012 & $\begin{array}{l}\text { Multicenter } \\
\text { (Europe) }\end{array}$ & Retrospective cohort & Costs of CKD treatment & $\begin{array}{l}\text { Secondary hyperparathyroidism increases } \\
\text { the financial burden of CKD in Europe. }\end{array}$ \\
\hline Kerr (44) & 2012 & England & Cross-sectional & Costs of CKD treatment & $\begin{array}{l}\text { The financial impact of CKD is high, with } \\
\text { high costs related to RRT and cardiovascular } \\
\text { complications. }\end{array}$ \\
\hline
\end{tabular}


Research has warned that CKD is one of the most costly diseases in healthcare (38), and that its economic burden is already considerably high in the early stages, and can be equal to or greater than the costs attributed to cancer or cerebrovascular accident in adults ${ }^{8}$. With the progression of the disease and the need to initiate dialysis, there is a significant increase in direct costs related to health maintenance ${ }^{15}$

When comparing the financial expenditures related to the modalities of RRT, patients who are not on dialysis and kidney transplant patients are considered less costly to healthcare systems than those on dialysis ${ }^{9}$. Among dialysis, hemodiafiltration, a form of HD, is considered as a cost-effective therapeutic option ${ }^{22}$. In contrast to HD, PD stood out as a lower cost option ${ }^{10,19}$. In Spain, HD is five times more expensive than the treatment of the more advanced stages of CKD and three times more expensive than transplantat ${ }^{33}$. Continuous ambulatory peritoneal dialysis was mentioned as the most efficient use of institutional and family resources ${ }^{31}$.

In Sweden, in relation to the healthcare costs of the general population, patients on HD, PD and kidney transplant present a 45, 29 and 11 times higher cost, respectively ${ }^{14}$. In Australia, CKD patients represent an $85 \%$ higher healthcare cost and require 50\% more government subsidies than the general population ${ }^{23}$.

In Brazil, HD and kidney transplant stand out because of the high costs, which may be related to the high prevalence of the two modalities in the country12. In India, costs associated with transplant are considered catastrophic and are responsible for a serious financial crisis $^{42}$.

The socioeconomic profile of chronic kidney disease patients was highlighted in several articles as a relevant factor in the outcomes. Higher mortality was found among those with low income, unemployed ${ }^{11}$, males and the elderly ${ }^{12}$. In addition, evidence shows that the prevalence of CKD increases considerably in the elderly ${ }^{34}$.

A study carried out in England showed that the main causes of death in chronic kidney patients were not related to kidney problems but to heart disease, and that despite this, CKD added to hospital costs high values in the last 12 months of life $^{14}$. In India, hospital costs of CKD patients were found to be substantially higher than those without $\mathrm{CKD}^{32}$.

In diabetic patients, progression of CKD makes treatment more costly ${ }^{37}$ and the direct costs of hospital admissions of patients with kidney complications are considerably higher than those without this complication $^{32}$. In addition, CKD is responsible for the

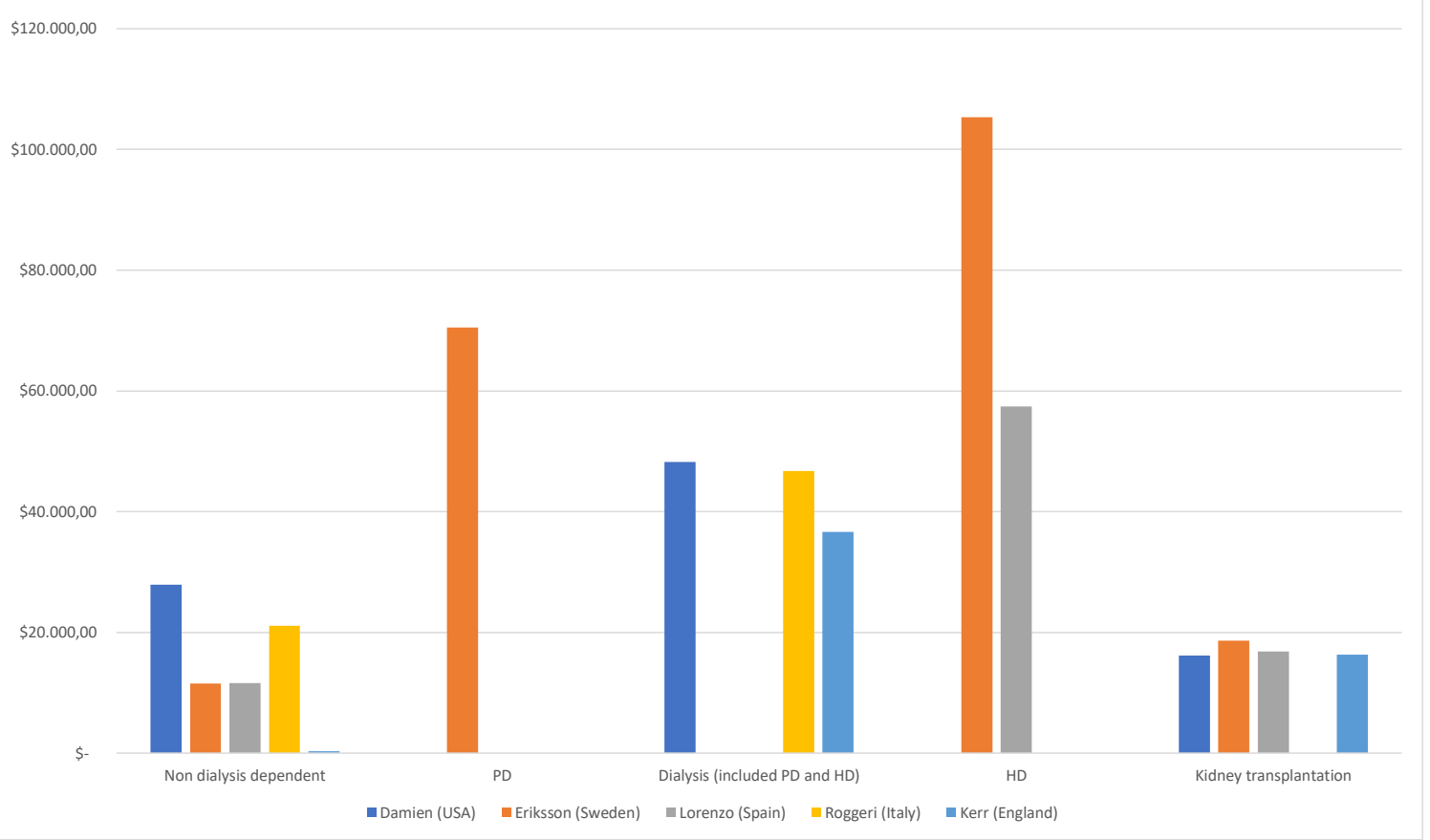


increase in expenses borne by DM patients, which strengthens the finding that it is the most expensive complication ${ }^{24}$. Other clinical conditions that, when associated with CKD, further increase their financial burden are autosomal polycystic kidney disease ${ }^{26,27}$ and secondary hyperparathyroidism ${ }^{43}$.

The financial repercussions of CKD treatment also have a strong impact on the economic structure of families ${ }^{18,40}$. A study points out that, for parents with chronic kidney disease children, the main culprits are the impossibility of maintaining employment and high expenses related to treatment ${ }^{28}$. Other research also highlights school drop-out as one of the consequences of treating the disease ${ }^{42}$.

With a view to reducing CKD financial expenditures, studies suggest that clinical follow-up before and after initiation of dialysis and management of comorbidities are potential sources of savings in CKD care $^{9}$. In specific cases, home death is associated with reduced hospital $\operatorname{costs}^{14}$ and that some clinical criteria may guide the diagnosis of CKD and reduce its costs ${ }^{16}$.

Figure 2 summarizes the annual costs of treating CKD in different modalities in different countries. Despite the characteristics of the analyses of the articles of this review, such as the variability of the factors included in the total expenditure and year of the study, when presented graphically, the costs of the CKD treatment show a significant difference between the different modalities of treatment, with haemodialysis having the highest cost.

\section{DISCUSSION}

Chronic kidney disease (CKD) has been gaining major repercussion due to its increasing incidence and prevalence worldwide, becoming a serious public health problem. The treatment of CKD is costly and, therefore, it is necessary to discuss possible cost reduction solutions, especially in Brasil, where political and economic crises are repeatedly faced. Although the methods and analyses are diverse, the results of the studies incorporated in this review are unanimous in alerting about the strong financial and social impact of CKD that affects the public and private healthcare systems, patients with the disease, family members and society as a whole. It is noted that the costs of CKD, compared to data from several countries, are higher in the long term for renal replacement therapies, especially in the haemodialysis modality. Transplant, despite being a high-cost surgi- cal procedure, has become more cost-effective over the years, not to mention improving patient survival and quality of life.

Although the economic repercussions of CKD in developing countries are even more serious in the face of the economic difficulties faced in various sectors, it is observed that these are not different in developed countries. A study carried out in Italy concluded that annual costs for patients undergoing CKD treatment before dialysis were set at EUR 11,123 (approximately USD 13,668) versus EUR 53,764 (approximately USD 66,067 ) for dialysis patients, proving that prevention, early diagnosis and the consequent delay in starting dialysis could considerably reduce healthcare sector expenditures ${ }^{15}$ also in countries with a more stable economy.

In the United States, considering the population served by Medicare, aged 65 or over, the total costs for parties A (Hospital Insurance, or HI) and B (Supplementary Medical Insurance, or SMI) increased by $11.5 \%$ to USD 227.100 million between 2008 and 2012 , while such costs rose $53.6 \%$ to USD 44.6 billion among patients with CKD. The costs for patients with CKD and DM increased $70.2 \%$ between 2008 and 2012, while similar costs for patients without CKD, DM or congestive heart disease increased by only $4.1 \%{ }^{45}$.

In India, the average monthly cost of HD in the city of Mumbai, for example, was INR 6,142.33 (approximately USD 92), while the per capita income in the country was INR 5,130 (approximately USD 77), according to data from 2011-2012, that is, the majority of patients were not able to pay for the treatment of CKD, since there are no state HD programs in the country $^{18}$, and this cost in India is significantly lower than in others countries analysed in our study, even lower than in Brasil. However, there is insufficient data to explain the reasons for this lower cost. It is estimated that in 2010 there were 2.6 million people on dialysis and $93 \%$ lived in countries with middle-high or high incomes, but the estimated number of people around the world who needed RRT was 4.9 to 9 million, indicating that approximately 2.3 million people died due to lack of access to adequate CKD care ${ }^{6}$.

In Brasil, most of the specialized services (secondary and tertiary care) that have the treatment modalities of CKD are linked to the Brazilian Healthcare System (SUS), representing one of the biggest bottlenecks in the system, which currently faces serious management and transfer of resources prob- 
lems. According to an article of the Folha de S.Paulo newspaper, on March 29, 2014, for every BRL 100 (approximately USD 30) invested in healthcare, BRL 54 (approximately USD 15) come from the families and corporate investment, and only BRL 46 (approximately USD 13) come from the public sector. According to experts, among the countries that adopt the universal healthcare system, Brasil is the only one where government healthcare spending is lower than private investment. It should be remembered that Brasil is the country with the largest public and universal healthcare system, and therefore should invest a much larger amount of public capital in the healthcare sector. In the United Kingdom, public sector spending accounts for $83 \%$ of the total; in Canada, 70.4\% and in Argentina, $61 \%^{46}$.

Regarding the Human Development Index (HDI), in the comparison between different countries, there is a proportional association with the transplant rate $^{47}$. In 2014, Norway ranked first in the global HDI ranking (0.944) and performed 53.5 kidney transplants per million population (pmp), while in the same period, Brasil ranked $75^{\text {th }}$ in the HDI $(0.755)$ and performed 29.6 transplants $\mathrm{pmp}^{48,49}$. It is emphasized that the goal for the country is to reach 50 kidney transplants pmp by $2018^{49}$.

Based on the evidence that kidney transplant is the mode of treatment for CKD with better clinical and quality of life outcomes, these data show that, although developed countries feel the financial repercussions of the CKD, their citizens are in a privileged position, in terms of access to the best therapeutic options. The HDI ratio and number of transplants also reveals the intrinsic association between CKD and financial support, because although the magnitude of the disease is transcultural, clinical outcomes are irremediably dependent on adequate funding.

Using Brasil as a reference, it was observed that in an analysis of the years 2008 and 2013 (last report available), about BRL 61.8 and BRL 189 million (approximately USD 17 and 55 million) were spent, respectively, in kidney transplants, that is, in the five-year period, the increase in expenditures was $300 \%{ }^{50}$. However, in the same period, kidney transplants increased only $67.6 \%{ }^{49}$. This disparity may be related to the improvement of surgical techniques, the incorporation of new less invasive technologies; to the use of new, more potent and more reliable immunosuppressive drugs, both in induction and maintenance therapy after transplant, and in the treatment of rejections; to the growth of transplant teams in number and staff; and greater longevity of patients and grafts, which generate a greater prevalence of outpatient visits in post-transplant follow-up. However, if this trend of rising charges continues, funding for the healthcare system will be seriously compromised in the future.

Given the high costs and complexity of treatments, the trend is for greater visibility to healthcare at the secondary and tertiary levels, but the results of this review point to the urgency of investing in primary care as a viable alternative for containment of expenses related to CKD.

Therapeutic interventions in the early stages of CKD are proven effective in slowing its progression. Considering that CKD, in general, is based on diseases such as hypertension and DM, continuous follow-up of patients and their families, screening new cases in the population, increasing the chances of early diagnosis, and implementing treatment for preserving kidney function are actions that need to be firmly incorporated into healthcare service practices, with emphasis on those offering basic care.

Increasing numbers of CKD and the high material and immaterial values involved in treatment modalities in a context of scarce resources have alerted to the need to develop tools and implement policies to control disease progression, aiming to reduce need for dialysis, transplant and complications.

\section{CONCLUSIONS}

It can be seen that the economic impact of CKD is global. It reaches all countries, regardless of the level of development and the model of healthcare. The studies analysed warn of the importance of primary and secondary prevention of CKD as a healthcare economy strategy. The association between population aging and the expansion of NCDs requires countries to reformulate care strategies and target their healthcare systems. The magnitude of the situation can be verified through the high incidence rates and prevalence of CKD, which is a complication of chronic diseases such as hypertension and DM. Massively investing in prevention and measures to slow the progression of CKD to the final stages, and hence avoid the need for dialysis and transplant, can represent a huge, not yet calculated, economy for patients and healthcare systems worldwide. 


\section{RESUMO}

O objetivo deste estudo é discutir os custos financeiros mundiais atribuídos à doença renal crônica (DRC) e suas repercussões sobre os sistemas de saúde em países em desenvolvimento, como o Brasil. Trata-se de uma revisão sistemática realizada na base de dados do PubMed/Medline, utilizando os termos em inglês "costs" e "chronic kidney disease", em janeiro de 2017. A busca foi ampliada a outros bancos, como o Scielo e o Google Acadêmico, com o objetivo de identificar estudos locais relacionados ao assunto, publicados em revistas não indexadas no PubMed. Foram incluídos apenas artigos publicados a partir de 2012. Priorizaram-se estudos que abordavam os custos da DRC e das modalidades de tratamento. A busca resultou em 392 artigos, dos quais foram excluídos 291 por fugirem da temática principal desta revisão. Dos 101 restantes, foram excluídos revisões, comentários e protocolos. Foram incluídos 37 artigos cujo foco eram os custos globais relacionados à DRC. Apesar de os métodos e análises serem diversos, os resultados dos estudos são unânimes em alertar sobre o forte impacto, financeiro e social, da DRC que atinge os sistemas de saúde, públicos e privados, portadores da doença, familiares e a sociedade. Investir maciçamente em prevenção e nas medidas para retardar a progressão da DRC para os estágios finais e, consequentemente, evitar a necessidade de diálise e transplante, podem representar uma enorme, e ainda não calculada, economia para pacientes e sistemas de saúde do mundo todo.

PALAVRAS-CHAVE: Insuficiência renal crônica. Diálise. Transplante de rim. Custos de cuidados de saúde.

\section{REFERENCES}

1. Kidney Disease: Improving Global Outcomes (KDIGO) CKD Work Group. KDIGO 2012 Clinical Practice Guideline for the Evaluation and Management of Chronic Kidney Disease. Kidney Inter Suppl. 2013;3:1-150.

2. Sesso RC, Lopes AA, Thomé FS, Lugon JR, Santos DR. Inquérito Brasileiro de Diálise Crônica 2013 - Análise das tendências entre 2011 e 2013. J Bras Nefrol. 2014;36(4):476-81.

3. Tonelli M, Riella M. Doença renal crônica e o envelhecimento da população. J Bras Nefrol. 2014;36(1):1-5.

4. Instituto Brasileiro de Geografia e Estatística (IBGE). Brasil: uma visão geográfica e ambiental no início do século XXI / Adma Hamam de Figueiredo (org). Rio de Janeiro: IBGE, Coordenação de Geografia, 2016. 435p.

5. Organização Mundial de Saúde (OMS). Relatório Mundial de Envelhecimento e Saúde (Resumo) 2015. Acesso em Fevereiro 2017. Disponível em: http://apps.who.int/iris/bitstream/10665/186468/6/WHO_ FWC_ALC_15.01_por.pdf

6. Nugent RA, Fathima SF, Feigl AB, et al. The Burden of Chronic Kidney Disease on Developing Nations: A 21st Century Challenge in Global Health. Nephron Clin Pract. 2011;118:269-277.

7. Garcia-Garcia G, Jha V. CKD in Disadvantaged Populations. | Bras Nefrol. 2015;37(1):14-18.

8. Small C, Kramer HJ, Griffin KA, et al. Non-dialysis dependent chronic kidney disease is associated with high total and out-of-pocket healthcare expenditures. BMC Nephrol. 2017;18:3.

9. Damien P, Lanham HJ, Parthasarathy M, et al. Assessing key cost drivers associated with caring for chronic kidney disease patients. BMC Health Serv Res. 2016;16(1):690.

10. Eriksson JK, Neovius M, Jacobson SH, et al. Healthcare costs in chronic kidney disease and renal replacement therapy:a population-based cohort study in Sweden. BMJ Open. 2016;6:e012062.

11. Anutrakulchai S, Mairian P, Pongskul C, et al. Mortality and treatment costs of hospitalized chronic kidney disease patients between the three major health insurance schemes in Thailand. BMC Health Serv Res. 2016;16:528.

12. Silva AT, Soares LB, Magajewski FRL. Epidemiologic and Economic Aspects Related to Hemodialysis and Kidney Transplantation in Santa Catarina in the Period of 2012-2013. Transplantat Proc. 2016;48(7):2284-2288.

13. Turchetti $G$, Bellelli $S$, Amato $M$, et al. The social cost of chronic kidney disease in Italy. Eur J Health Econ. 2016. doi 10.1007/s10198-016-0830-1

14. Kerr M, Matthews B, Medcalf JF, et al. End-of-life care for people with chronic kidney disease: cause of death, place of death and hospital costs. Nephrol Dial Transplant. 2016;0:1-6.

15. Roggeri DP, Roggeri A, Salomone M. Chronic Kidney Disease: Evolution of Healthcare Costs and Resource Consumption from Predialysis to Dialysis in Piedmont Region, Italy. Advances in Nephrology 2014; 1-6.

16. Mendu ML, Lundquist $A$, Aizer AA, et al. Clinical Predictors of Diagnostic Testing Utility in the Initial Evaluation of Chronic Kidney Disease. Nephrology (Carlton). 2016;21(10): 851-859.

17. Silva SB, Caulliraux HM, Araújo CAS, et al. Uma comparação dos custos do transplante renal em relação às diálises no Brasil. Cad. Saúde Pública. 2016;32(6):e00013515.

18. Kulkarni MJ, Jamale T, Hase NK, et al. A Cross-Sectional Study of Dialysis Practice-Patterns in Patients with Chronic Kidney Disease on Maintenance Hemodialysis. Saudi J Kidney Dis Transpl 2015;26(5):1050-56.

19. Atapour A, Eshaghian A, Taheri D, et al. Hemodialysis Versus Peritoneal Dialysis, Which is Cost-effective? Saudi J Kidney Dis Transpl 2015;26(5):962-965

20. Ferguson TW, Zacharias I, Walker SR. An Economic Assessment Model of Rural and Remote Satellite Hemodialysis Units. PLOS ONE. 2015;10(8):e0135587.

21. Francis ER, Kuo CC, Bernabe-Ortiz A, et al. Burden of chronic kidney disease in resource-limited settings from Peru: a population-based study. BMC Nephrology. 2015;16:114.

22. Takura T. Cost-effectiveness of hemodialysis in Japan. Contrib Nephrol. 2015;185:124-31.

23. Wyld MLR, Lee CMY, Zhuo X, et al. Cost to government and society of chronic kidney disease stage 1-5: a national cohort study. Intern Med J. 2015;45(7):741-7.

24. Ozieh MN, Dismuke CE, Lynch CP, et al. Medical care expenditures associated with chronic kidney disease in adults with diabetes: United States 2011. Diabetes Res Clin Pract. 2015;109(1):185-90.

25. Kent S, Schlackow I, Lozano-Kühne J, et al.What is the impact of chronic kidney disease stage and cardiovascular disease on the annual cost of hospital care in moderate-to-severe kidney disease? BMC Nephrology. 2015;16:65

26. Brunelli SM, Blanchette CM, Claxton AJ, et al. End-stage renal disease in autosomal dominant polycystic kidney disease: a comparison of dialysis-related utilization and costs with other chronic kidney diseases. Clinicoecon Outcomes Res. 2015;7:65-72.

27. Blanchette CM, Craver C, Belk KW, et al. Hospital-based inpatient resource utilization associated with autosomal dominant polycystic kidney disease in the US. J Med Econ. 2015;18(4):303-11.

28. Medway M, Tong A, Craig JC, et al. Parental Perspectives on the Financial Impact of Caring for a Child With CKD. Am J Kidney Dis. 2015;65(3):384393.

29. Menezes FG, Barreto DV, Abreu RM, et al. Panorama do tratamento hemodialítico financiado pelo Sistema Único de Saúde - Uma perspectiva econômica. J Bras Nefrol 2015;37(3):367-378.

30. Nassir BA, Dean CE, Li S, et al.Variation in Cost and Quality in Kidney Transplantation. Transplantation. 2015;99(10):2150-7.

31. Villarreal-Ríos E, Cárdenas-Maldonado C, Vargas-Daza ER, et al. Institutional and familial cost of patients in continuous ambulatory peritoneal dialysis. Rev Assoc Med Bras 2014; 60(4):335-341.

32. Satyavani $K$, Kothandan $H$, Jayraman $M$, et al. Direct costs associated with chronic kidney disease among type 2 diabetic patients in India. Indian J Nephrol. 2014; 24(3): 141-147.

33. Lorenzo-Sellares V, Pedrosa MI, Santana-Expósito B, et al. Análisis de 
costes y perfil sociocultural del enfermo renal. Impacto de la modalidad de tratamento. Nefrologia 2014;34(4):458-68

34. Moura L, Prestes IV, Duncan BB, et al. Dialysis for end stage renal disease financed through the Brazilian National Health System, 2000 to 2012. BMC Nephrol 2014, 15:111.

35. Gador-Whyte AP, Wakerman I, Campbell D, et al. Cost of best-practice primary care management of chronic disease in a remote Aboriginal community. Med ) Aust. 2014; 200(11):663-6.

36. Karopadi AN, Mason G, Rettore E, et al. The role of economies of scale in the cost of dialysis across the world: a macroeconomic perspective. Nephrol Dial Transplant. 2014;29:885-892.

37. Vupputuri S, Kimes TM, Calloway MO, Christian JB, Bruhn D, Martin AA, Nichols GA. The economic burden of progressive chronic kidney disease among patients with type 2 diabetes. I Diabetes Complications. 2014;28(1):10-16.

38. Kadam UT, Uttley |, Jones PW, et al. Chronic disease multimorbidity transitions across healthcare interfaces and associated costs: a clinical-linkage database study. BMJ Open. 2013;3(7):e003109.

39. Coentrão LA, Araújo CS, Ribeiro CA, et al. Cost analysis of hemodialysis and peritoneal dialysis access in incident dialysis patients. Perit Dial Int. 2013;33(6): 662-670.

40. Essue BM, Wong G, Chapman J, et al. How are patients managing with the costs of care for chronic kidney disease in Australia? A cross-sectional study. BMC Nephrol. 2013;14:5.

41. Erdem E, Prada SI, Haffer SC. Medicare Payments: How Much Do Chronic Conditions Matter? Medicare Medicaid Res Rev. 2013;3(2).

42. Ramachandran R, Jha V. Kidney Transplantation Is Associated with Catastrophic Out of Pocket Expenditure in India. PLoS One. 2013;8(7):e67812.
43. Chiroli S, Mattin C, Belozeroff V et al. Impact of mineral and bone disorder on healthcare resource use and associated costs in the European Fresenius medical care dialysis population: a retrospective cohort study. BMC Nephrol. 2012; 13:140

44. Kerr M, Bray B, Medcalf f, et al. Estimating the financial cost of chronic kidney disease to the NHS in England. Nephrol Dial Transplant. 2012;27(3): iii73-iii80.

45. United States Renal Data System, 2014 Annual Data Report: Epidemiology of Kidney Disease in the United States. National Institutes of Health, National Institute of Diabetes and Digestive and Kidney Diseases. Bethesda, MD, 2014. [acesso em 8 Julho 2015] Disponível em: http://www.usrds.org

46. Folha de São Paulo on line. Setor privado gasta mais que o governo na área da saúde. Acesso em 27 Junho 2015. Disponível em: http://www1.folha.uol.com.br/seminariosfolha/2014/03/1432494-setor-privado-gastamais-que-o-governo-na-area-da-saude.shtml

47. Garcia GG, Harden P, Chapman |. O papel global do transplante renal. | Bras Nefrol 2012;34(1):1-7.

48. Programa das Nações Unidas para o Desenvolvimento no Brasil. Acesso em Janeiro de 2017. Disponível em: http://www.br.undp.org/content/brazil/pt/home/idho/rankings/idh-global.html.

49. Associação Brasileira de Transplantes de Órgãos (ABTO). Registro Brasileiro de Transplantes 2015. Dimensionamento dos Transplantes no Brasil e em cada estado (2008-2015). Acesso em 29 dezembro 2016. Disponivel em: http://www.abto.org.br/abtov03/default.aspx$? \mathrm{mn}=561 \& \mathrm{c}=1086 \& \mathrm{~s}=0$ \&friendly=rbt-2015

50. Portal da Saúde. Ministério da Saúde [Homepage na internet]. Orientação e Prevenção - Transplantes. Acesso em 29 dezembro 2016. Disponível em: http://portalsaude.saude.gov.br 